\title{
Discovery of Potent Anilide Inhibitors against the Severe Acute Respiratory Syndrome 3CL Protease
}

\author{
Jiun-Jie Shie, ${ }^{\dagger}$ Jim-Min Fang, ${ }^{*}, \dagger, \ddagger$ Chih-Jung Kuo, ${ }^{\S}$ Tun-Hsun Kuo ${ }^{\S}$ Po-Huang Liang, ${ }^{*}$, Hung-Jyun Huang, ${ }^{\dagger}$ \\ Wen-Bin Yang, ${ }^{\ddagger}$ Chun-Hung Lin, ${ }^{\S}$ Jiun-Ling Chen ${ }^{\dagger}{ }^{\prime}$ Yin-Ta Wu, ${ }^{\ddagger}$ and Chi-Huey Wong ${ }^{\ddagger}, \|$ \\ Department of Chemistry, National Taiwan University, Taipei, 106, Taiwan, Genomics Research Center, Academia Sinica, \\ Taipei, 115, Taiwan, Institute of Biological Chemistry, Academia Sinica, Taipei, 115, Taiwan, and Department of Chemistry \\ and the Skaggs Institute for Chemical Biology, The Scripps Research Institute, La Jolla, California 92037
}

Received February 28, 2005

A diversified library of peptide anilides was prepared, and their inhibition activities against the SARS-CoV 3CL protease were examined by a fluorogenic tetradecapeptide substrate. The most potent inhibitor is an anilide derived from 2-chloro-4-nitroaniline, L-phenylalanine and 4-(dimethylamino)benzoic acid. This anilide is a competitive inhibitor of the SARS-CoV 3CL protease with $K_{\mathrm{i}}=0.03 \mu \mathrm{M}$. The molecular docking experiment indicates that the $\mathrm{P} 1$ residue of this anilide inhibitor is distant from the nucleophilic SH of Cys145 in the active site.

\section{Introduction}

Severe Acute Respiratory Syndrome (SARS) first occurred in Guandong (China) in November of 2002 and spread through many countries in 2003. This illness is caused by infection with a novel human coronavirus (SARS-CoV). ${ }^{1}$ The fatality rate of SARS-CoV infection is rather high, estimated to be $14-15 \%$. In only a few months, nearly 1000 lives were claimed. ${ }^{2}$ The natural source of SARS-CoV is unclear, though studies on the molecular evolution of SARS-CoV indicate that the virus may have emerged from wild animals. ${ }^{3}$ At present, no efficacious therapy for SARS is available. Therefore, a search for effective antivirals for the SARS-CoV is of current interest.

SARS coronavirus is a positive-strand RNA virus, ${ }^{4}$ that encodes two replicase polyproteins pp1a and pp1b. Extensive proteolytic processing of these nonstructural polyproteins is required to provide the functional proteins for viral propagation. These processes are mediated primarily by the main protease ( $\left.\mathrm{M}^{\text {pro }}\right)$, which is also known as dimeric chymotrypsin-like protease (3CL $\left.{ }^{\text {pro }}\right){ }^{5}$ The active site of SARS-CoV 3CL protease contains Cys145 and His41 to constitute a catalytic dyad, in which cysteine functions as the common nucleophile in the proteolytic process. ${ }^{5}$ The $3 \mathrm{CL}$ protease cleaves pp1a at no less than 11 conserved sites with a sequence of (Leu,Met,Phe)-Gln $\downarrow$ (Ser,Ala,Gly), in which a P1 glutamine residue invariably occupies the $\mathrm{S} 1$ site. ${ }^{5,6}$ The $3 \mathrm{CL}$ protease is essential for the propagation of the virus and thus serves as a key target for the discovery of antiSARS drugs.

So far, only a few inhibitors have been validated by in vitro protease assays. These protease inhibitors include $C 2$ symmetric peptidomimetic compounds, ${ }^{7}$ zincconjugated compounds, ${ }^{8}$ bifunctional aryl boronic acids, ${ }^{9}$ a quinolinecarboxylate derivative, ${ }^{10}$ a thiophenecar-

* To whom correspondence should be addressed. Tel: 886223637812. Fax: 8862-23636359. E-mail: jmfang@ntu.edu.tw.

${ }^{\dagger}$ National Taiwan University.

¥ Genomics Research Center, Academia Sinica.

\& Institute of Biological Chemistry, Academia Sinica.

" The Scripps Research Institute.

boxylate, ${ }^{11}$ and phthalhydrazide-substituted ketoglutamine analogues. ${ }^{12}$

As a part of our efforts directed toward the development of anti-SARS agents, we prepared several chromogenic peptides (AA) $)_{x}$-Gln-pNA, e.g. QTSITSAVLQpNA containing a $p$-nitroaniline moiety at the $C$-terminal glutamine, to test their activities as substrates for the SARS-CoV 3CL protease. Unlike typical nitroanilidebased peptides which are readily hydrolyzed by serine and cysteine proteases,${ }^{13}$ these $(\mathrm{AA})_{x}$-Gln-pNA peptides were not efficiently cleaved by the SARS-CoV 3CL protease but displayed weak inhibition against the enzyme. This observation, along with an earlier cellbased assay showing the inhibitory activity of $\mathrm{N}$-(2chloro-4-nitrophenyl)-5-chloro-2-hydroxybenzamide (Niclosamide) against the replication of SARS-CoV, ${ }^{14}$ led us to explore peptide nitroanilides as inhibitors of the SARS-CoV 3CL protease.

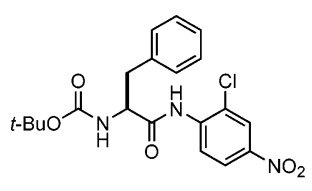

1
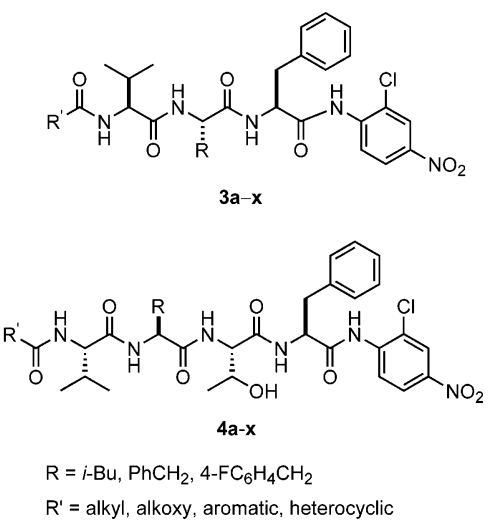

\section{Results and Discussion}

We chose to prepare a series of peptide anilides having L-phenylalanine as the $\mathrm{P} 1$ residue, on the basis 
Scheme 1. Synthesis of Ketomethylene Isosteres of Tripeptides ${ }^{a}$

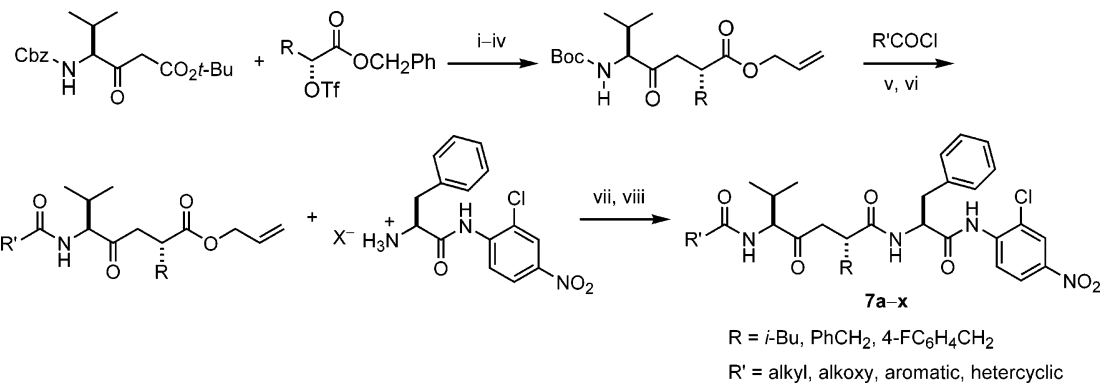

${ }^{a}$ Reagents and conditions: (i) $\mathrm{NaH}, \mathrm{THF}, 0{ }^{\circ} \mathrm{C}$ to room temperature, $24 \mathrm{~h}$. (ii) $\mathrm{CF}_{3} \mathrm{CO}_{2} \mathrm{H}, \mathrm{CH}_{2} \mathrm{Cl}_{2}, \mathrm{rt}, 24 \mathrm{~h}$. (iii) $\mathrm{H}_{2}, \mathrm{Pd} / \mathrm{C}, \mathrm{Boc} 2 \mathrm{O}, \mathrm{MeOH}$, rt, $10 \mathrm{~h}$. (iv) allyl iodide, $\mathrm{Cs}_{2} \mathrm{CO}_{3}, \mathrm{DMF}, 45^{\circ} \mathrm{C}, 5 \mathrm{~h}$. (v) $\mathrm{HCl}, 1,4$-dioxane, rt, $2 \mathrm{~h}$. (vi) $N$-methylmorpholine, $\mathrm{CH}_{2} \mathrm{Cl}_{2}, 0-25{ }^{\circ} \mathrm{C}, 2 \mathrm{~h}$. (vii) $\mathrm{Pd}\left(\mathrm{PPh}_{3}\right)_{4}$, morpholine, THF, $25{ }^{\circ} \mathrm{C}, 3 \mathrm{~h}$. (viii) HOBt, EDCI, $(i \text {-Pr })_{2} \mathrm{NEt}, \mathrm{CH}_{2} \mathrm{Cl}_{2}, 0{ }^{\circ} \mathrm{C}$ to room temperature, $20 \mathrm{~h}$.

of another study on AG7088 analogues that the inhibitory activity can be improved by using L-phenylalanine to replace L-glutamine or its $\gamma$-lactam isostere (see Table 3 in Supporting Information). Anilide 1 was prepared by condensation of 2-chloro-4-nitroaniline with the acyl chloride derivative of Boc-Phe-OH. Using the previously reported amide formation in a microtiter plate, ${ }^{15}$ the coupling reactions of a 60-member library of carboxylic acids with the amine generated by removal of the Boc group from anilide $\mathbf{1}$ afforded a 60-member library of anilide 2. Tripeptide anilides $\mathbf{3 a}-\mathbf{x}(24$ members $)$ and tetrapeptide anilides $\mathbf{4 a}-\mathbf{x}$ (24 members) were also created by coupling of $\mathbf{1}$ with appropriate peptides. The dimeric peptide anilides $\mathbf{5 a}-\mathbf{c}$ and $\mathbf{6 a}-\mathbf{c}$ were prepared by using a diacid, e.g. succinic acid, $S$-malic acid, and $(2 R, 3 R)$-tartaric acid, as the core structure to link with appropriate amino acids or peptides.

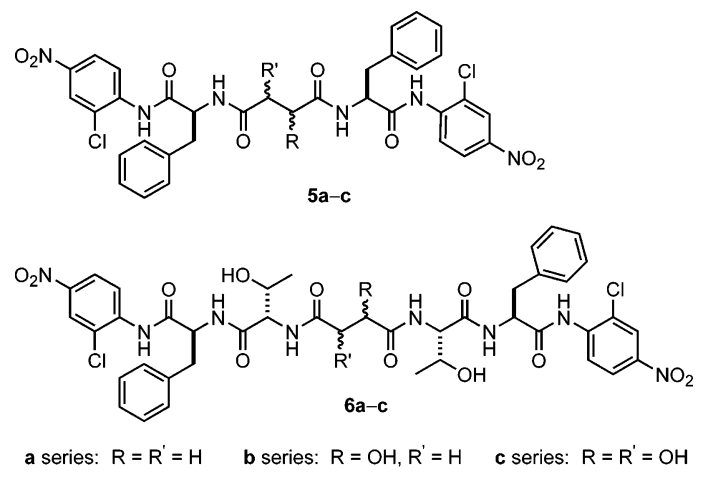

On the basis of the previously reported synthesis of AG7088, ${ }^{16}$ we also devised an expedient method for the synthesis of anilides $\mathbf{7 a}-\mathbf{x}$, the ketomethylene isosteres of tripeptides $\mathbf{3 a}-\mathbf{x}$ (Scheme 1).

These anilide products $\mathbf{2}-\mathbf{7}$ were characterized by mass analyses and directly subjected, without isolation, to the inhibition assay against the SARS-CoV 3CL protease according to the previously described fluorometric method. ${ }^{7,17}$ The initial velocities of the inhibited reactions using $50 \mathrm{nM}$ of SARS-CoV 3CL protease and $6 \mu \mathrm{M}$ of the fluorogenic substrate were plotted against the different inhibitor concentrations to obtain the $\mathrm{IC}_{50}$ values. On the basis of the preliminary results of assays, some of the most promising inhibitor candidates were selected for the scale-up synthesis. The $\mathrm{IC}_{50}$ values and inhibition constants $\left(K_{\mathrm{i}}\right)$ of the pure samples were then measured to validate their activities.

The results of preliminary assays indicated that the 2-chloro-4-nitroanilides 2-6 generally possessed good

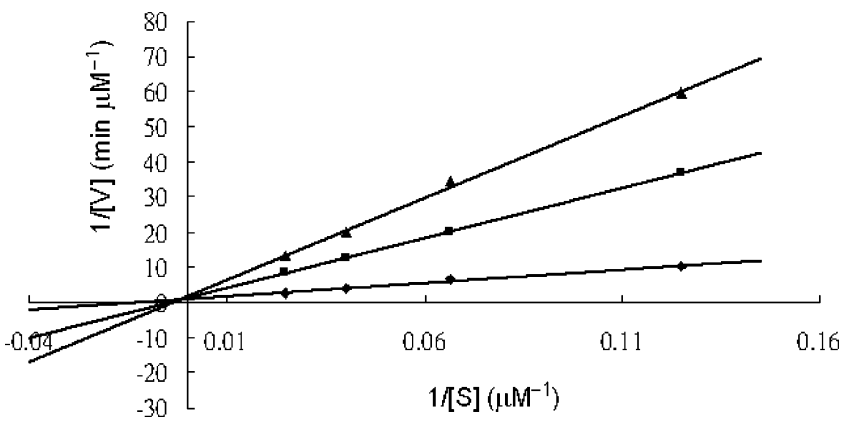

Figure 1. Lineweaver-Burk plot for inhibition of the SARSCoV 3CL protease by anilide $2 \mathbf{a}\left(K_{\mathrm{i}}=0.03 \mu \mathrm{M}\right)$.

inhibitory activities against the SARS-CoV 3CL protease, whereas the ketomethylene isosteres 7 were less potent than the tripeptide counterpart 3. Surprisingly, Niclosamide showed no inhibitory activity at a concentration of $50 \mu \mathrm{M} .^{8}$ The $\mathrm{IC}_{50}$ data for some anilide inhibitors, either prepared in microtiter plate without isolation or in pure form, are listed in Table 1. Anilide 2a (JMF1507) derived from 2-chloro-4-nitroaniline, Lphenylalanine, and 4-(dimethylamino)benzoic acid is the most potent inhibitor, showing an $\mathrm{IC}_{50}$ of $0.06 \mu \mathrm{M}$ and $K_{\mathrm{i}}=0.030 \mu \mathrm{M}$.

Lineweaver-Burk plots of kinetic data were fitted with the computer program KinetAsyst II (IntelliKinetics, PA) by nonlinear regression to obtain the $K_{\mathrm{i}}$ values. The double reciprocal plot of the initial rate vs substrate concentration indicates that all these compounds are competitive inhibitors. A representative example for inhibition of the SARS-CoV 3CL protease by anilide $\mathbf{2 a}$ is shown in Figure 1. It is worth to note that anilide $\mathbf{2 a}$ functions as a potent inhibitor with $K_{\mathrm{i}}=0.03 \mu \mathrm{M}$, rather than a substrate for the SARS-CoV 3CL protease. The HPLC and absorption spectral analyses indicated that no decomposition of anilide $\mathbf{2 a}$ occurred under the enzymatic conditions for a period over $16 \mathrm{~h}$ (see the Supporting Information). In hydrolysis of $N$-nitrophenylamide, alignment of $n, \pi$-orbitals is required for the facile leaving of nitroaniline. Due to the steric effect of the chlorine atom at the ortho-position, the 2-chloro-4nitrophenyl ring and amido group cannot be in a coplanar conformation, thus making hydrolysis unfavorable. This speculation is in agreement with the computer modeling shown in Figure 2.

To know the structure-activity relationship, a series of the $\mathbf{2 a}$ analogues was synthesized and the inhibitory activity was examined. None of the analogues 8a-f showed adequate activity $\left(\mathrm{IC}_{50}>10 \mu \mathrm{M}\right)$. Deletion of 
Table 1. IC $_{50}$ Values for Some 2-Chloro-4-nitroanilide Inhibitors against the SARS-CoV 3CL Protease

\begin{tabular}{|c|c|c|c|c|c|}
\hline structure type & compd & $\mathrm{R}$ & $\mathrm{R}^{\prime}$ & $\mathrm{IC}_{50}(\mu \mathrm{M})$ & $K_{\mathrm{i}}(\mu \mathrm{M})^{a}$ \\
\hline niclosamide & & & & $>50^{a}$ & \\
\hline \multirow[t]{6}{*}{ anilide } & 1 & & $t-\mathrm{BuO}$ & $>50^{a}$ & \\
\hline & $\mathbf{2 a}$ & & $\mathrm{Me}_{2} \mathrm{NC}_{6} \mathrm{H}_{4}$ & $0.06^{a}$ & $0.03 \pm 0.001$ \\
\hline & $2 \mathbf{b}$ & & $\mathrm{C}_{14} \mathrm{H}_{29} \mathrm{CH}(\mathrm{Br})$ & $3^{b}$ & \\
\hline & 2c & & $3,4-\left(\mathrm{NH}_{2}\right)_{2} \mathrm{C}_{6} \mathrm{H}_{3}$ & $2^{b}$ & \\
\hline & 2d & & (indol-3-yl)- $\mathrm{CH}=\mathrm{CH}$ & $3^{b}$ & \\
\hline & $\mathbf{2 e}$ & & $\left(2-\mathrm{NH}_{2}-1,3\right.$-thiazol-4-yl $)-\mathrm{C}\left(=\mathrm{NOCH}_{3}\right)$ & $7^{b}$ & \\
\hline \multirow[t]{7}{*}{ tripeptide anilide } & $\mathbf{3 a}$ & $i-\mathrm{Bu}$ & Et & $7^{b}$ & \\
\hline & $3 \mathbf{c}$ & $i-\mathrm{Bu}$ & $\mathrm{Ph}$ & $4^{b}$ & \\
\hline & $\mathbf{3 d}$ & $i-\mathrm{Bu}$ & $t-\mathrm{BuO}$ & $>10^{a}$ & \\
\hline & 3f & $i-\mathrm{Bu}$ & morpholino & $19^{b}$ & \\
\hline & $\mathbf{3 h}$ & $i-\mathrm{Bu}$ & thien-2-yl & $5^{a}$ & $2.29 \pm 1.01$ \\
\hline & 30 & $\mathrm{PhCH}_{2}$ & 5-Me-isoxazol-3-yl & $7^{a}$ & $2.90 \pm 1.27$ \\
\hline & $3 \mathbf{p}$ & $\mathrm{PhCH}_{2}$ & Thien-2-yl & $5^{a}$ & $4.3 \pm 1.9$ \\
\hline \multirow[t]{7}{*}{ tetrapeptide anilide } & $4 \mathbf{a}$ & $i$-Bu & Et & $7^{b}$ & \\
\hline & 4f & $i-\mathrm{Bu}$ & morpholino & $16^{b}$ & \\
\hline & $4 \mathrm{~g}$ & $\mathrm{PhCH}_{2}$ & $t-\mathrm{Bu}$ & $2^{b}$ & \\
\hline & $\mathbf{4 j}$ & $\mathrm{PhCH}_{2}$ & 5-Me-isoxazol-3-yl & $5^{a}$ & $1.61 \pm 1.03$ \\
\hline & $4 \mathbf{k}$ & $\mathrm{PhCH}_{2}$ & $\mathrm{PhCH}_{2} \mathrm{O}$ & $6^{a}$ & $1.51 \pm 0.95$ \\
\hline & $\mathbf{4 q}$ & $4-\mathrm{FC}_{6} \mathrm{H}_{4} \mathrm{CH}_{2}$ & Et & $5^{b}$ & \\
\hline & $4 s$ & $4-\mathrm{FC}_{6} \mathrm{H}_{4} \mathrm{CH}_{2}$ & $\mathrm{Ph}$ & $2^{b}$ & \\
\hline \multirow{6}{*}{ dimeric anilide } & $\mathbf{5 a}$ & $\mathrm{H}$ & $\mathrm{H}$ & $>50^{b}$ & \\
\hline & $5 \mathbf{b}$ & $(S)-\mathrm{OH}$ & $\mathrm{H}$ & $4^{a}$ & $3.1 \pm 0.4$ \\
\hline & $\mathbf{5 c}$ & $(R)-\mathrm{OH}$ & $(R)-\mathrm{OH}$ & $5^{b}$ & \\
\hline & $\mathbf{6 a}$ & $\mathrm{H}$ & $\mathrm{H}$ & $2^{b}$ & \\
\hline & $\mathbf{6 b}$ & $(S)-\mathrm{OH}$ & $\mathrm{H}$ & $2^{b}$ & \\
\hline & $6 c$ & $(R)-\mathrm{OH}$ & $(R)-\mathrm{OH}$ & $2^{b}$ & \\
\hline \multirow[t]{7}{*}{ ketomethylene anilide } & $7 \mathbf{a}$ & $i$-Bu & Et & $27^{b}$ & \\
\hline & $7 \mathrm{c}$ & $i-\mathrm{Bu}$ & $\mathrm{Ph}$ & $21^{b}$ & \\
\hline & $7 d$ & $i-\mathrm{Bu}$ & $t-\mathrm{BuO}$ & $19^{b}$ & \\
\hline & $7 f$ & $i-\mathrm{Bu}$ & morpholino & $29^{b}$ & \\
\hline & $7 \mathrm{~h}$ & $i-\mathrm{Bu}$ & thien-2-yl & $22^{b}$ & \\
\hline & 7o & $\mathrm{PhCH}_{2}$ & 5-Me-isoxazol-3-yl & $6^{b}$ & \\
\hline & $7 p$ & $\mathrm{PhCH}_{2}$ & Thien-2-yl & $16^{b}$ & \\
\hline
\end{tabular}

${ }^{a}$ The sample is in pure form. ${ }^{b}$ The sample is synthesized in a microtiter plate and assayed in situ without isolation.

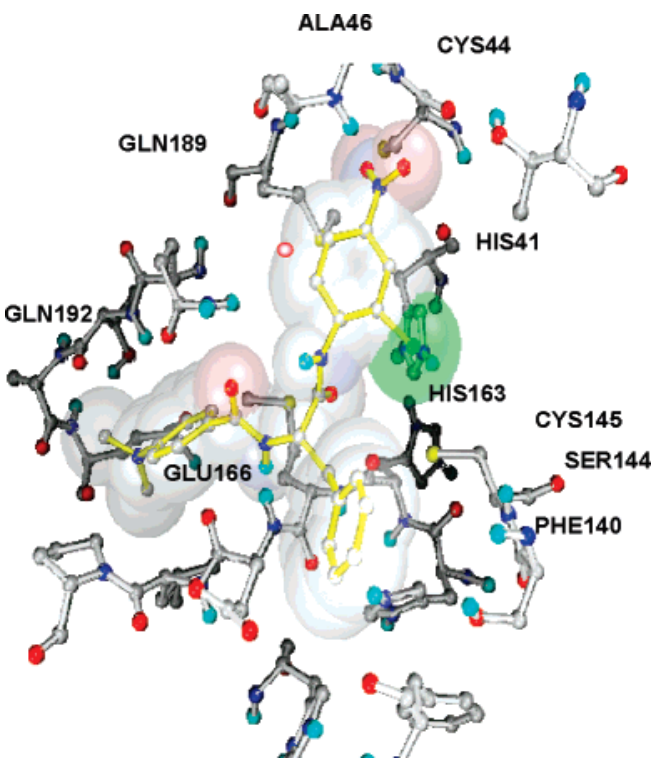

Figure 2. Computer modeling of compound $\mathbf{2 a}$ binding to SARS-CoV 3CL protease (1uk4). Compound 2a is colored in yellow. The van der Waals filling space is generated by 1.0 scale and colored according to atom type. Clusters of possible docking modes were sorted by computed binding free energy and the docking mode with lowest docking energy $(-9.1 \mathrm{kcal} /$ mol in this case) is generated by MGLTOOLS.

the chloro, nitro, or dimethylamino substituents from anilide $\mathbf{2 a}$ significantly deteriorated potency as did replacing the dimethylamino group in $\mathbf{2 a}$ with a nitro group.
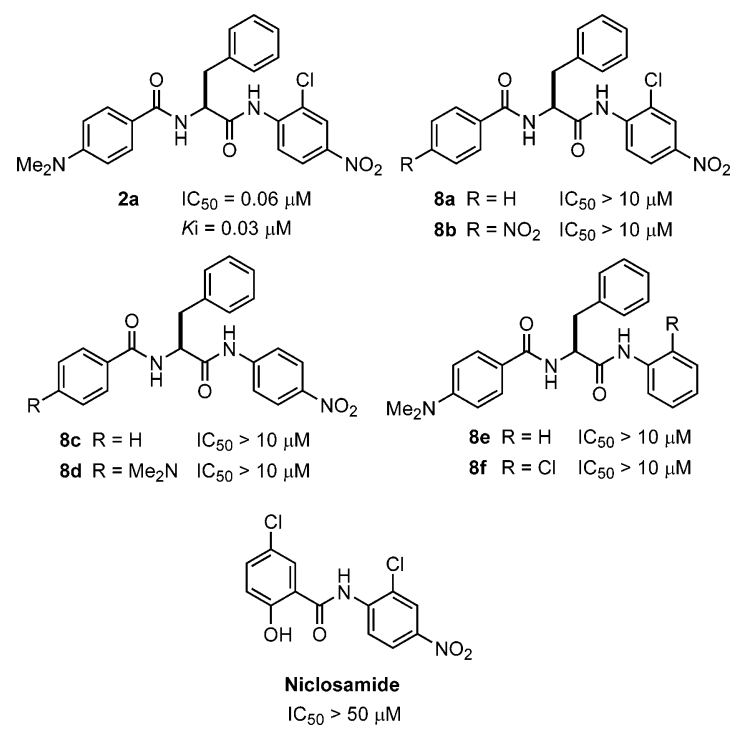

The crystal structure of SARS-CoV 3CL protease in complex with a specific inhibitor of hexapeptidyl chloromethyl ketone, Cbz-Val-Asn-Ser-Thr-Leu-Gln- $\mathrm{CH}_{2} \mathrm{Cl}$, has been reported (coded 1uk4 in the Protein Data Bank deposition). ${ }^{5 \mathrm{~b}}$ On this basis, the docking experiment (Autodock version 3.0.5) ${ }^{18}$ using $p$-nitroaniline as the core structure formed three main clusters $(\mathrm{RMSD}=2$ $\AA$ A). The clusters with lowest binding free energy occupies 
the pocket formed by Cys145, Ser144, His163, and Phe140 or the pocket formed by Thr25, His41, Cys44, Thr45, and Ala46. The 2-chloro-4-nitroanilide moiety of 2a was found to occupy the second favorite pocket described above (Figure 2). The nitro group in $\mathbf{2 a}$ is predicted to be hydrogen bonded with the $\mathrm{HN}$ of Ala46, while the chlorine atom is within $3 \AA$ from $\gamma$-S atom of Cys145 and $\epsilon$-N2 atom of His41, providing a possible key interaction with the catalytic dyad. The (dimethylamino)phenyl group is fitted to the cleft formed by Gln189-Gln192 and Met165-Pro68. The P1 phenyl residue in $\mathbf{2 a}$ is positioned in the $\mathrm{S} 1$ pocket, which may be modified to increase the interactions with Phe140, His163, and Glu166.

The docking study showed that anilide $\mathbf{2 a}$ has the lowest binding free energy of $-9.1 \mathrm{kcal} / \mathrm{mol}$ in comparison with the anilides $8 \mathbf{a}-\mathbf{e}\left(\Delta G^{*}=-7.5\right.$ to $-8.7 \mathrm{kcal} /$ mol, see the Supporting Information). This docking experiment supports the observation in the enzymatic assay, which reveals the important roles of the 2-chloro4-nitroanilide and (dimethylamino)phenyl moieties in inhibition of the SARS-CoV 3CL protease. The docking model also shows that the $\mathrm{P} 1$ site of anilide $\mathbf{2 a}$ is distant $(\sim 4.95 \AA)$ from the nucleophilic SH of Cys145. This model is in agreement with the observation that anilide $\mathbf{2 a}$ is stable in the SARS 3CL protease.

Under the assay conditions similar to that for the SARS-CoV 3CL protease, the $\mathrm{IC}_{50}$ values of anilide $\mathbf{2 a}$ against trypsin, chymotrypsin, and papain were measured to be 110,200 , and $220 \mu \mathrm{M}$, respectively. In comparison, anilide $\mathbf{2 a}$ is a potent inhibitor for the SARS-CoV 3CL protease with an $\mathrm{IC}_{50}$ value of $0.06 \mu \mathrm{M}$.

\section{Experimental Section}

Materials and Methods. SARS-CoV 3CL protease was prepared according to the previously described procedure. ${ }^{17}$ Reactions requiring dry conditions were carried out under an inert atmosphere using standard techniques. All the reagents and solvents were reagent grade and were used without further purification unless otherwise specified. THF was distilled from sodium benzophenone ketyl under $\mathrm{N}_{2}$.

Representative Procedure of Coupling Reactions. A solution of $N$-Boc phenylalanine $(2.65 \mathrm{~g}, 10 \mathrm{mmol})$ and 2-chloro4-nitroaniline (1.73 g, $10 \mathrm{mmol})$ in pyridine $(30 \mathrm{~mL})$ was cooled to $-15{ }^{\circ} \mathrm{C}$, and phosphorus oxychloride $(1 \mathrm{~mL}, 11 \mathrm{mmol})$ was added dropwise with vigorous stirring. After the mixture was stirred for $1.5 \mathrm{~h}$ at $-15{ }^{\circ} \mathrm{C}$, the reaction was quenched by pouring into ice-water $(100 \mathrm{~mL})$. The mixture was extracted with EtOAc $(1 \times 50 \mathrm{~mL}$ and $3 \times 30 \mathrm{~mL})$. The combined organic phase was washed with saturated $\mathrm{NaHCO}_{3}(2 \times 50 \mathrm{~mL})$ and brine $(30 \mathrm{~mL})$. The organic phase was dried over $\mathrm{MgSO}_{4}$ and filtered, and the filtrate was concentrated under reduced pressure. The residue was purified by flash silica gel column chromatography with elution of EtOAc/hexane (5:95) to give $\mathrm{N}$-Boc phenylalanine 2-chloro-4-nitroanilide (1, 3.25 g, 78\%) as white solids.

A solution of $N$-Boc phenylalanine 2-chloro-4-nitroanilide (0.42 g, $1 \mathrm{mmol})$ in 1,4-dioxane $(3 \mathrm{~mL})$ was treated with a solution of $\mathrm{HCl}$ in 1,4-dioxane $(4 \mathrm{M}, 2 \mathrm{~mL})$ at $25{ }^{\circ} \mathrm{C}$. The mixture was stirred for $1.5 \mathrm{~h}$ and concentrated under reduced pressure to give a crude aminium chloride salt. The material was dissolved in $\mathrm{CH}_{2} \mathrm{Cl}_{2}(5 \mathrm{~mL})$, cooled to $0{ }^{\circ} \mathrm{C}$, and treated with 4-methylmorpholine $(0.3 \mathrm{~mL}, 2.5 \mathrm{mmol})$ and 4-(dimethylamino)benzoyl chloride $(0.22 \mathrm{~g}, 1.2 \mathrm{mmol})$ sequentially. The ice bath was removed, and the mixture was stirred for $2 \mathrm{~h}$ at $25{ }^{\circ} \mathrm{C}$. The reaction was quenched by addition of brine $(15 \mathrm{~mL})$. The mixture was extracted with $\mathrm{CH}_{2} \mathrm{Cl}_{2}(2 \times 20 \mathrm{~mL})$. The organic phase was dried over $\mathrm{Na}_{2} \mathrm{SO}_{4}$ and filtered, and the filtrate was concentrated under reduced pressure. The residue was purified by flash column chromatography with elution of EtOAc/hexane (1:9) to provide $N$-[4-(dimethylamino)phenyl]phenylalanine 2-chloro-4-nitroanilide (2a, $0.29 \mathrm{~g}, 61 \%)$ as light yellow solids.

4-(Dimethylamino)benzoyl-L-Phe-(2-chloro-4-nitroanilide) (2a). Light yellow solid; $\mathrm{mp} 205-207{ }^{\circ} \mathrm{C} ; \lambda_{\max }=320$ $\mathrm{nm}$; TLC (EtOAc/hexane, 1:1) $R_{f}=0.5$; IR (KBr) 3304, 2926, $1710,1607,1512,1344,1279,1185 \mathrm{~cm}^{-1} ;{ }^{1} \mathrm{H} \mathrm{NMR}\left(\mathrm{CDCl}_{3}, 400\right.$ $\mathrm{MHz}) \delta 9.17(1 \mathrm{H}, \mathrm{s}), 8.67(1 \mathrm{H}, \mathrm{d}, J=9.2 \mathrm{~Hz}), 8.24(1 \mathrm{H}, \mathrm{d}, J$ $=2.4 \mathrm{~Hz}), 8.14(1 \mathrm{H}, \mathrm{dd}, J=9.2,2.4 \mathrm{~Hz}), 7.60(2 \mathrm{H}, \mathrm{d}, J=8.9$ $\mathrm{Hz}), 7.35-7.31(3 \mathrm{H}, \mathrm{m}), 7.30-7.27(2 \mathrm{H}, \mathrm{m}), 6.65(2 \mathrm{H}, \mathrm{d}, J=$ $8.9 \mathrm{~Hz}), 6.41(1 \mathrm{H}, \mathrm{d}, J=7.1 \mathrm{~Hz}), 5.08-5.06(1 \mathrm{H}, \mathrm{m}), 3.34(2$ $\mathrm{H}, \mathrm{d}, J=7.1 \mathrm{~Hz}), 3.04(6 \mathrm{H}, \mathrm{s}) ;{ }^{13} \mathrm{C} \mathrm{NMR}\left(\mathrm{CDCl}_{3}, 100 \mathrm{MHz}\right) \delta$ $170.5(\mathrm{C}), 168.1(\mathrm{C}), 152.9(\mathrm{C}), 143.0(\mathrm{C}), 140.4(\mathrm{C}), 136.2(\mathrm{CH})$, $129.3(\mathrm{C}), 129.0(\mathrm{CH}, 2 \times), 128.7(\mathrm{CH}, 2 \times), 127.4(\mathrm{CH}, 2 \times$ ), $124.7(\mathrm{CH}), 123.3(\mathrm{CH}), 122.9(\mathrm{C}), 120.4(\mathrm{C}), 119.2(\mathrm{CH})$, $111.0(\mathrm{CH}, 2 \times), 55.6(\mathrm{CH}), 40.0\left(\mathrm{CH}_{3}, 2 \times\right), 36.7\left(\mathrm{CH}_{2}\right) ; \mathrm{FAB}$ MS m/z 467.1 $\left(\mathrm{M}^{+}+\mathrm{H}\right)$; HRMS calcd for $\mathrm{C}_{24} \mathrm{H}_{24} \mathrm{ClN}_{4} \mathrm{O}_{4}$ : 467.1486 $\left(\mathrm{M}^{+}+\mathrm{H}\right)$; found: 467.1488; Anal. Calcd for $\mathrm{C}_{24} \mathrm{H}_{23^{-}}$ $\mathrm{ClN}_{4} \mathrm{O}_{4}$ : C 61.74, $\mathrm{H} 4.97, \mathrm{~N} 12.00$; found: C 61.71, H 5.01, N 11.96 .

Inhibition Assay against the SARS-CoV 3CL Protease. A fluorometric assay ${ }^{17}$ was utilized to determine the inhibition constants of the prepared samples. Briefly, a fluorogenic peptide Dabcyl-KTSAVLQSGFRKME-Edans is used as the substrate, and the enhanced fluorescence due to cleavage of this substrate catalyzed by the protease was monitored at 538 $\mathrm{nm}$ with excitation at $355 \mathrm{~nm}$. The $\mathrm{IC}_{50}$ value of individual sample was measured in a reaction mixture containing $50 \mathrm{nM}$ of the SARS 3CL protease and $6 \mu \mathrm{M}$ of the fluorogenic substrate in $20 \mathrm{mM}$ Bis-Tris ( $\mathrm{pH}$ 7.0). The enzyme stock solution was kept in $12 \mathrm{mM}$ Tris- $\mathrm{HCl}$ (pH 7.5) containing 120 $\mathrm{mM} \mathrm{NaCl}, 0.1 \mathrm{mM}$ EDTA, and $1 \mathrm{mM}$ DTT plus $7.5 \mathrm{mM} \beta$-ME before adding to the assay solution. The $K_{\mathrm{i}}$ measurements were performed at two fixed inhibitor concentrations and various substrate concentrations.

Acknowledgment. We thank National Science Council (Taiwan) for financial support, and Shih-Jia Shiao and Su-Lung Tang for preparation of some anilide inhibitors.

Supporting Information Available: Physical and spectroscopic properties of new compounds, inhibition assay, HPLC and UV-vis analyses, molecular modeling, and NMR spectra. This material is available free of charge via the Internet at http://pubs.acs.org.

\section{References}

(1) (a) Ksiazek, T. G.; Erdman, D.; Goldsmith, C. S.; Zaki, S. R. Peret, T.; Emery, S.; Tong, S.; Urbani, C.; Comer, J. A.; Lim, W.; Rollin, P. E.; Dowell, S. F.; Ling, A.-E.; Humphrey, C. D Shieh, W.-J.; Guarner, J.; Paddock, C. D.; Rota, P.; Fields, B.; DeRisi, J.; Yang, J.-Y.; Cox, N.; Hughes, J. M.; LeDuc, J. W. Bellini, W. J.; Anderson, L. J. A Novel Coronavirus Associated with Severe Acute Respiratory Syndrome N. Engl. J. Med. 2003 348, 1953-1966. (b) Drosten, C.; Günther, S.; Preiser, W.; van der Werf, S.; Brodt, H.-R.; Becker, S.; Rabenau, H.; Panning, M.; Kolesnikova, L.; Fouchier, R. A. M.; Berger, A.; Burguiere, A.-M.; Cinatl, J.; Eickmann, M.; Escriou, N.; Grywna, K.; Kramme, S.; Manuguerra, J.-C.; Muller, S.; Rickerts, V.; Sturmer, M.; Vieth, S.; Klenk, H.-D.; Osterhaus, A. D. M. E.; Schmitz, H.; Doerr, H. W. Identification of a Novel Coronavirus in Patients with Severe Acute Respiratory Syndrome. N. Engl. J. Med. 2003, 348, 1967-1976. (c) Peiris, J. S. M.; Lai, S. T.; Poon L. L. M.; Guan, Y.; Yam, L. Y. C.; Lim, W.; Nicholls, J.; Yee, W. K. S.; Yan, W. W.; Cheung, M. T.; Cheng, V. C. C.; Chan, K. H.; Tsang, D. N. C.; Yung, R. W. H.; Ng, T. K.; Yuen, K. Y Coronavirus as a Possible Cause of Severe Acute Respiratory Syndrome Lancet 2003, 361, 1319-1325.

(2) World Helth Organization, Communicable Disease Surveillance \& Response, website: http://www.who.int/csr/sars/archive/ $200305 \quad 07 \mathrm{a} / \mathrm{en}$ and $\mathrm{http}: / / \mathrm{www} . \mathrm{who.int/csr/sars/country/en/}$ country2003_08_15.pdf. Summary table of SARS cases by country (1 November 2002 to 7 August 2003).

(3) He, J.-F.; Peng, G.-W.; Min, J.; Yu, D.-W.; Liang, W.-J.; Zhang, S.-Y.; Xu, R.-H.; Zheng, H.-Y.; Wu, X.-W.; Xu, J.; Wang, Z.-H Fang, L.; Zhang, X.; Li, H.; Yan, X.-G.; Lu, J.-H.; Hu, Z.-H.; Huang, J.-C.; Wan, Z.-Y.; Hou, J.-L.; Lin, J.-Y.; Song, H.-D.; Wang, S.-Y.; Zhou, X.-J.; Zhang, G.-W.; Gu, B.-W.; Zheng, H.- 
J.; Zhang, X.-L.; He, M.; Zheng, K.; Wang, B.-F.; Fu, G.; Wang, X.-N.; Chen, S.-J.; Chen, Z.; Hao, P.; Tang, H.; Ren, S.-X.; Zhong, Y.; Guo, Z.-M.; Liu, Q.; Miao, Y.-G.; Kong, X.-Y.; He, W.-Z.; Li, Y.-X.; Wu, C.-I.; Zhao, G.-P.; Chiu, R. W. K.; Chim, S. S. C.; Tong, Y.-k.; Chan, P. K. S.; Tam, J. S.; Lo, Y. M. D. Molecular Evolution of the SARS Coronavirus During the Course of the SARS Epidemic in China. Science 2004, 303, 1666-1669.

(4) (a) Rota, P. A.; Oberste, M. S.; Monroe, S. S.; Nix, W. A.; Campagnoli, R.; Icenogle, J. P.; Penaranda, S.; Bankamp, B.; Maher, K.; Chen, M.-h.; Tong, S.; Tamin, A.; Lowe, L.; Frace, M.; DeRisi, J. L.; Chen, Q.; Wang, D.; Erdman, D. D.; Peret, T. C. T.; Burns, C.; Ksiazek, T. G.; Rollin, P. E.; Sanchez, A.; Liffick, S.; Holloway, B.; Limor, J.; McCaustland, K.; Olsen-Rasmussen, M.; Fouchier, R.; Günther, S.; Osterhaus, A. D. M. E.; Drosten, C.; Pallansch, M. A.; Anderson, L. J.; Bellini, W. J. Characterization of a Novel Coronavirus Associated with Severe Acute Respiratory Syndrome. Science 2003, 300, 1394-1399. (b) Marra, M. A.; Jones, S. J. M.; Astell, C. R.; Holt, R. A.; Brooks-Wilson, A.; Butterfield, Y. S. N.; Khattra J.; Asano, J. K.; Barber, S. A.; Chan, S. Y.; Cloutier, A.; Coughlin, S. M.; Freeman, D.; Girn, N.; Griffith, O. L.; Leach, S. R.; Mayo, M.; McDonald, H.; Montgomery, S. B.; Pandoh, P. K.; Petrescu, A. S.; Robertson, A. G.; Schein, J. E.; Siddiqui, A.; Smailus, D. E.; Stott, J. M.; Yang, G. S.; Plummer, F.; Andonov, A.; Artsob, H.; Bastien, N.; Bernard, K.; Booth, T. F.; Bowness, D.; Czub, M.; Drebot, M.; Fernando, L.; Flick, R.; Garbutt, M.; Gray, M.; Grolla, A.; Jones, S.; Feldmann, H.; Meyers, A.; Kabani, A.; Li, Y.; Normand, S. Stroher, U.; Tipples, G. A.; Tyler, S.; Vogrig, R.; Ward, D. Watson, B.; Brunham, R. C.; Krajden, M.; Petric, M.; Skowronski, D. M.; Upton, C.; Roper, R. L. The Genome Sequence of the SARS-Associated Coronavirus. Science 2003, 300, 1399-1404. (c) Ruan, Y.; Wei, C. L.; Lin, A. E.; Vega, V. B.; Thoreau, H.; Se Thoe, S. Y.; Chia, J. M.; Ng, P.; Chiu, K. P.; Lim, L.; Zhang, T.; Chan, K. P.; Lin, E. L. O.; Ng, M. L.; Leo, S. Y.; Ng, L. F.; Ren, E. C.; Stanton, L. W.; Long, P. M.; Liu, E. T. Comparative FullLength Genome Sequence Analysis of 14 SARS Coronavirus Isolates and Common Mutations Associated with Putative Origins of Infection. Lancet 2003, 361, 1779-1785.

(5) (a) Anand, K.; Ziebuhr, J.; Wadhwani, P.; Mesters, J. R.; Hilgenfeld, R. Coronavirus Main Proteinase (3CL pro) Structure: Basis for Design of Anti-SARS Drugs. Science 2003, 300, 17631767. (b) Yang, H.; Yang, M.; Ding, Y.; Liu, Y.; Lou, Z.; Zhou, Z.; Sun, L.; Mo, L.; Ye, S.; Pang, H.; Gao, G. F.; Anand, K.; Bartlam, M.; Hilgenfeld, R.; Rao, Z. The Crystal Structures of Severe Acute Respiratory Syndrome Virus Main Protease and Its Complex with an Inhibitor. Proc. Natl. Acad. Sci. U.S.A 2003, 100, 13190-13195. (c) Chou, K.; Wei, D.; Zhong, W. Binding Mechanism of Coronavirus Main Proteinase with Ligands and Its Implication to Drug Design Against SARS. Biochem. Biophys. Res. Commun. 2003, 308, 148-151.

(6) (a) Fan, K.; Wei, P.; Feng, Q.; Chen, S.; Huang, C.; Ma, L.; Lai, B.; Pei, J.; Liu, Y.; Chen, J.; Lai, L. Biosynthesis, Purification, and Substrate Specificity of Severe Acute Respiratory Syndrome Coronavirus 3C-Like Proteinase. J. Biol. Chem. 2004, 279, 1637-1642. (b) Huang, C.; Wei, P.; Fan, K.; Liu, Y.; Lai, L. 3CLike Proteinase from SARS Coronavirus Catalyzes Substrate Hydrolysis by a General Base Mechanism. Biochemistry 2004, 43, 4568-4574. (c) Du, Q.-S.; Wang, S.-Q.; Zhu, Y.; Wei, D.-Q.; Guo, H.; Sirois, S.; Chou, K.-C. Polyprotein Cleavage Mechanism of SARS CoV M ${ }^{\text {pro }}$ and Chemical Modification of the Octapeptide. Peptides 2004, 25, 1857-1864

(7) Wu, C.-Y.; Jan, J.-T.; Ma, H.-H.; Kuo, C.-J.; Juan, H.-F.; Cheng, Y.-S. E.; Hsu, H.-H.; Huang, H.-C.; Wu, D.; Brik, A.; Liang, F.S.; Liu, R.-S.; Fang, J.-M.; Chen, S.-T.; Liang, P.-H.; Wong, C.H. Small Molecules Targeting Severe Acute Respiratory Syndrome Human Coronavirus. Proc. Natl. Acad. Sci. U. S. A. 2004, $101,10012-10017$.
(8) Hsu, J. T.-A.; Kuo, C.-J.; Hsieh, H.-P.; Wang, Y.-C.; Huang, K.K.; Lina, C. P.-C.; Huang, P.-F.; Chen, X.; Liang, P.-H. Evaluation of Metal-Conjugated Compounds as Inhibitors of 3CL Protease of SARS-CoV. FEBS Lett. 2004, 574, 116-120.

(9) Bacha, U.; Barrila, J.; Velazquez-Campoy, A.; Leavitt, S. A.; Freire, E. Identification of Novel Inhibitors of the SARS Coronavirus Main Protease 3CL ${ }^{\text {pro }}$. Biochemistry 2004, 43, 49064912 .

(10) Kao, R. Y.; Tsui, W. H. W.; Lee, T. S. W.; Tanner, J. A.; Watt, R. M.; Huang, J.-D.; Hu, L.; Chen, G.; Chen, Z.; Zhang, L.; He, T.; Chan, K.-H.; Tse, H.; To, A. P. C.; Ng, L. W. Y.; Wong, B. C. W.; Tsoi, H.-W.; Yang, D.; Ho, D. D.; Yuen, K.-Y. Identification of Novel Small-Molecule Inhibitors of Severe Acute Respiratory Syndrome-Associated Coronavirus by Chemical Genetics. Chem. Biol. 2004, 11, 1293-1299.

(11) Blanchard, J. E.; Elowe, N. H.; Huitema, C.; Fortin, P. D.; Cechetto, J. D.; Eltis, L. D.; Brown1, E. D. High-Throughput Screening Identifies Inhibitors of the SARS Coronavirus Main Proteinase. Chem. Biol. 2004, 11, 1445-1453.

(12) Jain, R. P.; Pettersson, H. I.; Zhang, J.; Aull, K. D.; Fortin, P. D.; Huitema, C.; Eltis, L. D.; Parrish, J. C.; James, M. N. G.; Wishart, D. S.; Vederas, J. C. Synthesis and Evaluation of KetoGlutamine Analogues as Potent Inhibitors of Severe Acute Respiratory Syndrome 3CLpro. J. Med. Chem. (Web release date: Nov. 5, 2004).

(13) (a) Zhang, R.; Malcolm, B. A.; Beyer, B. M.; Njoroge, F. G.; Durkin, J. P.; Windsor, W. T. Peptide Substrates for Hepatitis C Virus NS3 Protease Assays. U.S. Patent, 2001, 21 pp. (b) Voelter, W.; Echner, H.; Philapitsch, A. Determining the C1Esterase Inhibitor Activity in a Sample. Ger. Offen. 1982, 22 pp. (c) Echner, H.; Voelter, W. New Chromogenic Substrates for Determination of Serine Proteases. Chemiker-Zeitung 1988, 112 , 117-124.

(14) Wu, C. J.; Jan, J. T.; Chen, C. M.; Hsieh, H. P.; Hwang, D. R.; Liu, H. W.; Liu, C. Y.; Huang, H. W.; Chen, S. C.; Hong, C. F.; Lin, R. K.; Chao, Y. S.; Hsu, J. T. A. Inhibition of Severe Acute Respiratory Syndrome Coronavirus Replication by Niclosamide. Antimicrob. Agents Chemother. 2004, 48, 2693-2696.

(15) (a) Wu, C.-Y.; Chang, C.-F.; Chen, J. S.-Y.; Wong, C.-H.; Lin, C.-H. Rapid Diversity-Oriented Synthesis in Microtiter Plates for In Situ Screening: Discovery of Potent and Selective $\alpha$-Fucosidase Inhibitors. Angew. Chem., Int. Ed. 2003, 42, 4661-4664. (b) Chang, C.-F.; Ho, C.-W.; Wu, C.-Y.; Chao, T.-A.; Wong, C.H.; Lin, C.-H. Discovery of Picomolar Slow Tight-Binding Inhibitors of $\alpha$-Fucosidase Chem. Biol. 2004, 11, 1301-1306.

(16) (a) Tian, Q.; Nayyar, N. K.; Babu, S.; Chen, L.; Tao, J.; Lee, S.; Tibbetts, A.; Moran, T.; Liou, J.; Guo, M.; Kennedy, T. P. An Efficient Synthesis of a Key Intermediate for the Preparation of the Rhinovirus Protease Inhibitor AG7088 via Asymmetric Dianionic Cyanomethylation of $\mathrm{N}$-Boc-L-(+)-Glutamic Acid Dimethyl Ester. Tetrahedron Lett. 2001, 42, 6807-6809. (b) Tian, Q.; Nayyar, N. K.; Babu, S.; Tao, J.; Moran, T. J.; Dagnino, R.; Mitchell, L. J.; Remarchuk, T. P.; Melnick, M. J.; Bender, S. L. Efficient Synthetic Routes for the Preparation of Rhinovirus Protease Inhibitors and Key Intermediates. U.S. Pat. Appl. 6,355,807, 2002, $25 \mathrm{pp}$

(17) Kuo, C.-J.; Chi, Y.-H.; Hsu, T.-A.; Liang, P.-H. Characterization of SARS Main Protease and Inhibitor Assay Using a Fluorogenic Substrate. Biochem. Biophys. Res. Commun. 2004, 318, 862867.

(18) Morris, G. M.; Goodsell, D. S.; Halliday, R. S.; Huey, R.; Hart, W. E.; Belew, R. K.; Olson, A. J. Automated Docking Using a Lamarckian Genetic Algorithm and an Empirical Binding Free Energy Function. J. Comput. Chem. 1998, 19, 1639-1662. 